\title{
Fundamentals of the Warburg Effect in Cancer
}

\author{
Pi Xian Zhang ${ }^{1}$, Ya Qi Xing ${ }^{2}$, Yong Dong Niu ${ }^{2}$ \\ ${ }^{I}$ Department of Biochemistry and Molecular Biology, Shantou University Medical College, Shantou, Guangdong 515041, China; \\ ${ }^{2}$ Department of Pharmacology, Shantou University Medical College, Shantou, Guangdong 515041, China
}

\begin{abstract}
As the fundamental energy unit of most cells, the ATP generated from glucose is vital to maintain biological processes such as the synthesis of proteins and nucleic acids. However, a common feature of cancer cells is an altered metabolism with increased glucose uptake and the fermentation of glucose to lactate even in the presence of normal mitochondria. This phenomenon is known as the 'Warburg effect' (now termed aerobic glycolysis). One simple explanation for this effect is that it permits cells to more easily produce energy to support rapid growth. It can also help to meet the biosynthetic requirements for pyruvate as a major building block. As a well-known metabolic hallmark of cancer cells, the role of the Warburg effect in oncology is a newly-emerging area of growing interest. In this perspective, we provide some new understanding of these mechanisms based on recent progress in research on cancer metabolism. The better understanding of these mechanisms will support the development of new therapeutic strategies that take into account tumor nutrition and energy metabolism.
\end{abstract}

Key words: Warburg effect; Cancer; Glycolysis; ATP; Lactate

\section{Introduction}

Limitless replicative potential and deregulated metabolism are universally accepted as hallmarks of carcinogenesis [1]. The rapid proliferation of cancer cells requires high amounts of nutrients and energy, and elevated biosynthetic activity to generate bio-macromolecules during each stage of the cell cycle. It is well known that cancer cells have a greater need for energy and building block molecules, which are necessary for the synthesis of macromolecular components during cell proliferation. It has long been considered that the altered metabolism, especial energy metabolism, in tumor cells is required to facilitate their rapid growth and duplication.

In 1923, Otto Warburg observed that cancer cells proliferate with accelerated glycolysis and excessive lactate formation, even when supplied by enough oxygen, although these processes only occurred in normal cells when there was insufficient oxygen [2-4]. According to Warburg's estimation, the arterial glucose uptake in tumor cells is about $47 \% \sim 70 \%$ compared to $2 \% \sim 18 \%$ in normal tissues, with tumor cells converting $66 \%$ of glucose to lactate [5]. Cancer cells prefer aerobic glycolysis to oxidative phosphorylation during ATP production $[6,7]$. This phenomenon was subsequently called the "Warburg effect" based on his initial observations $[4,8]$. In Warburg's opinion, this change might result in the impaired respiration and functional defects of mitochondria in cancer cells [7,9]. The Warburg effect has subsequently been observed in more than $70 \%$ of human cancers, including colorectal cancer [10], breast

Correspondence author: Yong Dong Niu, Department of Pharmacology, Shantou University Medical College, No.22 Xinling Road, Shantou, Guangdong 515041, China; Tel: +86 7548890 0432; Email: ydniu@126.com cancer [11], lung cancer [12], and glioblastoma [13,14]. Additionally, ubiquitous overexpression of glycolysisrelated genes has been noted in various human cancers [1517]. The lactate released from cancer cells was deemed to be a byproduct of cancer metabolism, and might be the basis of cell migration and metastasis [18-20], immune escape [21-24], poor survival [19], angiogenesis [20,25-27] and even overall cancer development $[4,28]$. The origins of lactate formation are still incompletely understood and are probably influenced by multiple factors [29-32], while the exact roles and the mechanisms underlying the Warburg effect in carcinogenesis are still being explored. Here, we focus on the mechanism of lactate production and discuss the possible regulation of the Warburg effect in cancer.

\section{Mitochondrial Dysfunction in Cancer Cells?}

In Otto Warburg's opinion, aerobic glycolysis, which releases lactate under normal oxygen conditions, was a preferential manner to meet the energy requirements for cancer cells' rapid growth and due to the mitochondrial dysfunction common in cancer cells [7,9]. For each molecule of glucose consumed, 2 ATP are produced by glycolysis, while 32 ATP molecules are produced by the oxidative phosphorylation pathway. Therefore, although the ATP generation via aerobic glycolysis is less efficient than oxidative phosphorylation, cancer cells are able to quickly produce sufficient energy by consuming huge quantities of glucose. Although inefficient, this allows cancer cells to maintain their abnormal biological functions, including rapid proliferation.

The factors that drive cancer cells to choose such an inefficient pathway, and the biological significance of the Warburg effect, have remained elusive. It was theorized that the increased rate of glycolysis could compensate for the energy requirements for cancer cells' rapid growth. 
This speculation was supported by later evidence [33-37], and was considered to be a mechanism responsible for the fast energy production and biosynthesis. Nevertheless, this theory has been challenged by many investigators. Early in 1967, Weinhouse S et al. observed that the glycolmetabolism of slow-growing rat hepatocytes was typically supported by oxidation [29]. Not only in cells with normal mitochondrial function [30-32], but also some tumor cells, have been reported to use oxidative phosphorylation as the major ATP supplier, regardless of the metabolic rate of glycolysis [38,39]. The mitochondrial membrane potential $(\triangle \Psi \mathrm{m})$ is mainly generated by the end-step of ATP production. NADH or FADH2 (Dihydroflavine-adenine dinucleotide) transfers electrons to oxygen molecules via the electron transport chain to form water, $\mathrm{NAD}^{+}$or $\mathrm{FAD}^{2+}$, thus releasing protons from the mitochondrial matrix outside of the mitochondrial inner membrane. As a result, the $\Delta \Psi \mathrm{m}$ can function as a powerful index for assessing mitochondrial activity $[40,41]$. When compared with the adjacent normal tissues, tumors always exhibit elevations in the mitochondrial membrane potential [42-47]. This suggests that oxidative phosphorylation may be preferred over glycolysis for efficient ATP production. Therefore, Warburg's theory about mitochondrial malfunction is not a reasonable explanation for the dominance of aerobic glycolysis in cancer cells. Thus, additional research has been performed to try to elucidate the main driving factor(s) underlying the high lactate release in tumor cells.

\section{Pyruvate Dehydrogenase Complex (PDC)- the Major Controller of Lactate Production in Tumor Cells}

It is well known that the canonical fate of pyruvate is to be converted into lactate through glycolysis (Figure 1) or completely oxidized to carbon dioxide, water and 32 ATPs by oxidative phosphorylation. Researchers have tried to explore the primary pathway by which cancer cells undergo pyruvate metabolism and the major factors controlling this process. Recent evidence has indicated that the pyruvate dehydrogenase complex (PDC) is crucial. The aerobic oxidation of glucose doesn't produce lactate, while glucose glycolysis does. The fundamental switch between these processes depends on the activity of the PDC, which catalyzes the rate-limiting oxidative decarboxylation of pyruvate into acetyl-CoA. PDC is only active in aerobic oxidation, not in glycolysis [48-50]. The major effect of PDC activity is controlling the flux of acetyl CoA converted from glucose. When the pathway is blocked, excessive pyruvate will return to the cytoplasm and form lactate and NADH.

Some recent studies demonstrated that there was inhibition of PDC activity in most tumors [51-55]. Inhibition of PDKs could induce PDC to reverse the Warburg effect [56]. On the other hand, enhancing the expression of pyruvate dehydrogenase kinase, PDK, could inactivate PDC, facilitating lactate generation from pyruvate [57-59]. Additionally, Mi- chelle Potter reported that when cancer cells were cultured in high $(25 \mathrm{mM})$ and low $(1 \mathrm{mM})$ glucose conditions, different extracellular acidification rates were observed. Cancer cells cultivated in the high $(25 \mathrm{mM})$ glucose condition had a high and dispersive extracellular acidification rate, while those cultured with $1 \mathrm{mM}$ glucose showed a very low and similar extracellular acidification rate [60]. This result suggested that treatment with a high concentration of glucose will lead to high levels of lactate production in cancer cells, which means that most pyruvate converted from glucose does not enter the mitochondrion to produce ATP, but is instead located in the cytoplasm, where it forms lactate. These findings also indicated that the activity of PDC is aberrant in cancer cells.

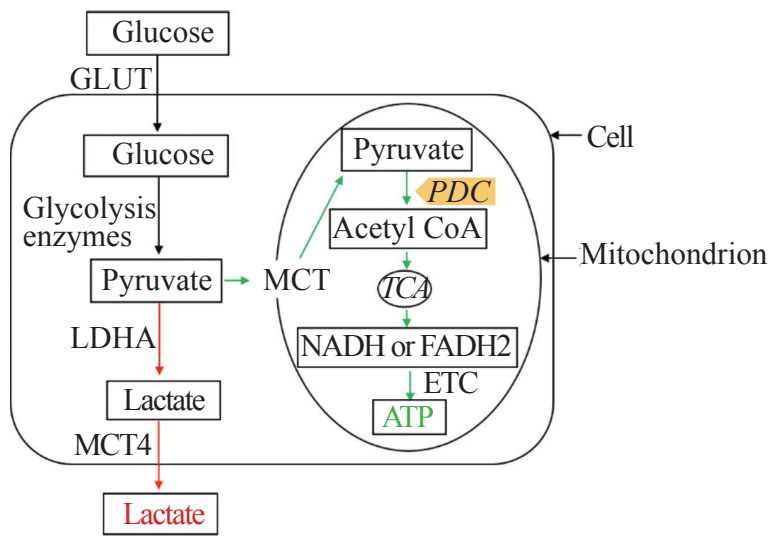

Figure 1 Glycolysis and the oxidative phosphorylation pathway. When ingested glucose is converted into pyruvate, two pathways exist to utilize it: glycolysis, as shown by the red arrows, and oxidative phosphorylation, as shown by the green arrows. The most important controller is pyruvate dehydrogenase complex, PDC. GLUT: glucose transporter; LDHA: lactate dehydrogenase A; MCT: monocarboxylate transporter; PDC: pyruvate dehydrogenase complex; TCA: tri-carboxylic acid cycle; NADH: nicotinamide adenine dinucleotide hydride; FADH2: flavin adenine dinucleotide hydride; ETC: electron transport chain; ATP: adenosine triphosphate

However, the major molecules controlling the PDC were unclear. The acetylation and succinylation of the PDC had recently been reported [61,62]. However, the phosphorylation of the PDC seems to be more important for its activity. PDKs are over-expressed in almost all kinds of cancers [63-73], and several studies have shown that PDKs play a major role in the metabolic adaptations that occur during the acquisition of the tumor metabolic phenotype [74-77].

\section{The Effects of NADH, and Their Importance in Controlling Lactate Production}

$\mathrm{NADH}$ is an allosteric inhibitor of PDC that can directly or indirectly restrain PDC activity. Additionally, it is an activator of PDKs. More importantly, NADH is required to produce lactate (Figure 2), as follows:

Pyruvate $+\mathrm{NADH} \rightarrow$ lactate $+\mathrm{NAD}^{+}$ 
Catalyzing enzymes are crucial for the fate of NADH. However, the end controller is the molecular balance, not the enzyme activity. For example, the reaction to produce lactate does not depend on LDHA activity, but rather the concentrations of reactants and products. Increased pyruvate, NADH and decreased lactate will promote the reaction to produce lactate. Therefore, it has been speculated that a high level of NADH in the cytoplasm could drive increased lactate production. In support of this, the production of active $\mathrm{NADH}$ in the cytoplasm and its importance for ATP production have been reported [47,7880].

Kim SY et al. found that cytosolic 10-formyltetrahydrofolate dehydrogenase (ALDH1L1) produces abundant cytosolic $\mathrm{NADH}$, which could be transported to the mitochondria via the malate-aspartate shuttle (MAS) in non-small-cell lung cancer cells (NSCLC). ALDH1L1 knockdown was found to reduce ATP production by $60 \%$. And an ALDH inhibitor, gossypol, combined with phenformin, a mitochondrial complex I inhibitor, significantly suppressed tumor growth

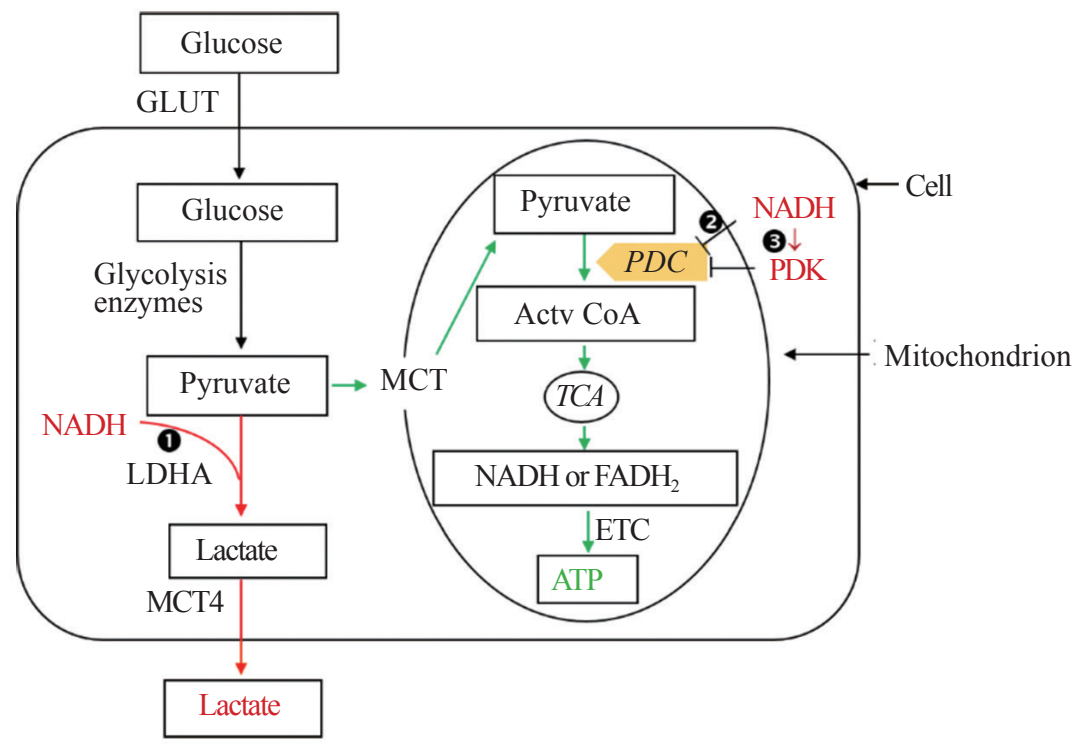

Figure 2 The influence of NADH on the production of lactate. (1) NADH, as a reactant, reacts with pyruvate to produce lactate and NAD+. (2) NADH, as a direct allosteric inhibitor of PDC, increases lactate production. (3) NADH, as an inhibitor of PDC, activates PDK, which inhibits PDC by phosphorylating it.

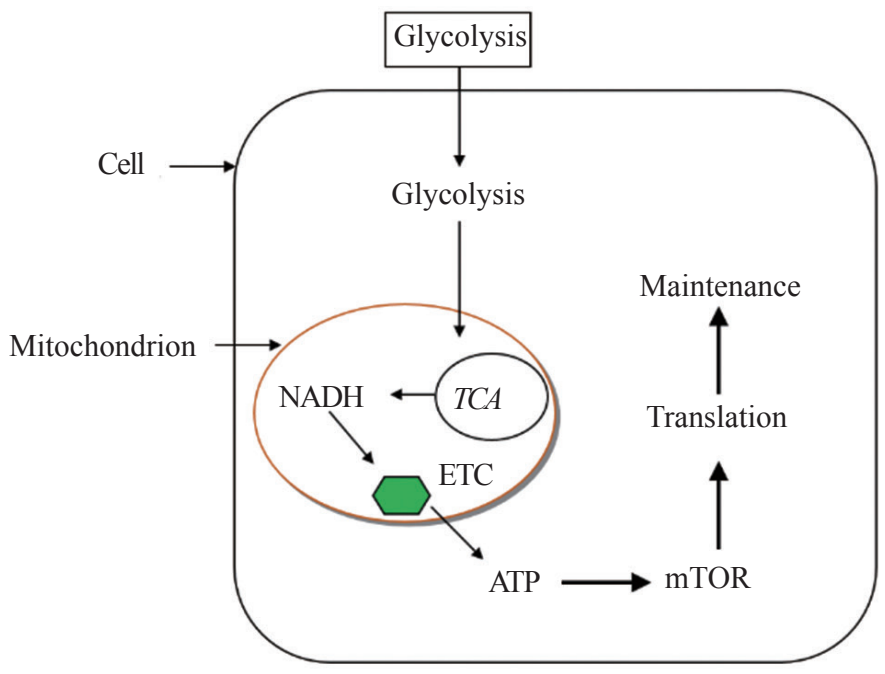

Normal Cell

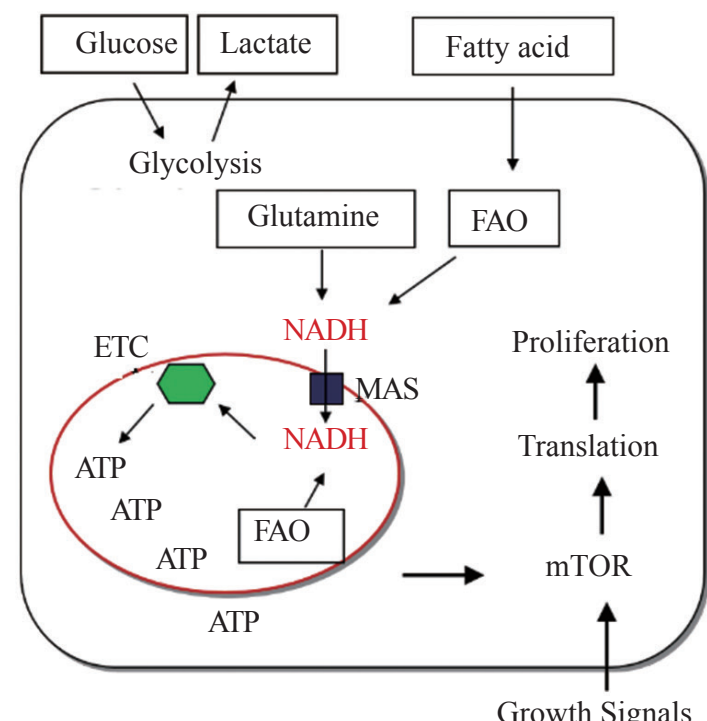

Cancer Cell

Figure 3 A new proposed model of cancer energy metabolism. The major source of electron may be cytosolic NADH produced by metabolic enzymes such as ALDH. ETC: electron transport chain; FAO: fatty acid oxidation; MAS: malate-aspartate shuttle; TCA: tricarboxylic acid cycle (This model originated from work by Kim SY et al. [79]). 
$[47,78,79]$. Kim SY et al. named this change in metabolism the "Cytosolic NADH theory" (Figure 3) [79]. In this model, lactate is not an essential factor for cell proliferation.

\section{Conclusion and Perspectives}

The "Cytosolic NADH theory" suggests that the increased ATP production is from cytosolic NADH. This $\mathrm{NADH}$ originates from the conversion of glutamine and FAO during cancer cell proliferation. This indicates that the first choice of material for energy utilization in cancer cells is amino acids and fats, not glucose. Based on this viewpoint, some researchers speculated that the energy supply for the cellular proliferation of tumors is not derived from glucose in non-glycotropic cancers. This association between cytosolic NADH and energy metabolism has been reported in NSCLC [78,81]. Although the change in the lactate level was not described in NSCLC, these factors would all be expected to influence the release of lactate. Although these discoveries are fascinating, there is still a long way to go to determine whether this is a common phenomenon.

Increasing research about the Warburg effect has given insight into the interpretation of its functions in the energy metabolism of cancer cells. However, there is much work still needed to elucidate how rapid proliferation is directly or indirectly regulated by cell metabolism. These uncertainties also highlighted the need to enhance our understanding of the biology and functions of the Warburg effect and its possible therapeutic potential in carcinogenesis. Recently, regulating the nutrient intake of cancer cells has been considered a possible therapeutic strategy, which may involve the exploitation of glycolytic inhibitors or PKM2 [82], PKM-1 [83], or metformin [84]. Obtaining a better understanding of the key principles and mechanisms underlying the Warburg effect in cancer cells will aid in the development of preventive and therapeutic approaches using dietary and pharmacological interventions.

\section{Conflict of interests}

The authors declare no conflict of interest.

\section{Funding}

This study was funded by the National Natural Science Foundation of China (81772972, 81572703), Guangdong Natural Science Foundation (2015A030313449), Guangdong Provincial Science and Technology Program (2014A020212285), the Department of Education, and the Guangdong Government under the Top-tier University Development Scheme for Research and Control of Infectious Diseases (2016026, 2015060, 2015089).

\section{References}

1. Hanahan D, Weinberg RA. Hallmarks of cancer: the next generation. Cell 2011;144(5):646-74.
2. Warburg O. Versuche an überlebendem carcinom-gewebe. Klin Wochenschr 1923;2:776-7.

3. Warburg O. über den stoffwechsel der carcinomzelle. Naturwissenschaften 1924;12:1131-7.

4. San-Millan I, Brooks GA. Reexamining cancer metabolism: lactate production for carcinogenesis could be the purpose and explanation of the Warburg Effect. Carcinogenesis 2017;38(2):119-33.

5. Warburg O, Wind F, Negelein E. The Metabolism of Tumors in the Body. J Gen Physiol 1927;8(6):519-30.

6. Warburg O. On the origin of cancer cells. Science 1956;123 (3191):309-14.

7. Warburg O. On respiratory impairment in cancer cells. Science 1956;124(3215):269-70.

8. Racker E. Bioenergetics and the problem of tumor growth: an understanding of the mechanism of the generation and control of biological energy may shed light on the problem of tumor growth. AmSci 1972;60:56-63.

9. Warburg O. On the origin of cancer cells. Science 1956;123(3191):30914.

10. Sakashita M, Aoyama N, Minami R, Maekawa S, Kuroda K, Shirasaka D, Ichihara T, Kuroda Y, Maeda S, Kasuga M. Glut1 expression in T1 and T2 stage colorectal carcinomas: its relationship to clinicopathological features. Eur J Cancer 2001;37(2):204-9.

11. Grover-McKay M, Walsh SA, Seftor EA, Thomas PA, Hendrix MJ. Role for glucose transporter 1 protein in human breast cancer. Pathol Oncol Res 1998;4(2):115-20.

12. Wu M, Neilson A, Swift AL, Moran R, Tamagnine J, Parslow D, Armistead S, Lemire K, Orrell J, Teich J, Chomicz S, Ferrick DA. Multiparameter metabolic analysis reveals a close link between attenuated mitochondrial bioenergetic function and enhanced glycolysis dependency in human tumor cells. Am J Physiol Cell Physiol 2007;292(1):C12536.

13. Lai JH, Jan HJ, Liu LW, Lee CC, Wang SG, Hueng DY, Cheng YY, Lee HM, Ma HI. Nodal regulates energy metabolism in glioma cells by inducing expression of hypoxia-inducible factor 1alpha. Neuro Oncol 2013;15(10):1330-41.

14. Michelakis ED, Sutendra G, Dromparis P, Webster L, Haromy A, Niven E, Maguire C, Gammer TL, Mackey JR, Fulton D, Abdulkarim B, McMurtry MS, Petruk KC. Metabolic modulation of glioblastoma with dichloroacetate. Sci Transl Med 2010;2(31):31ra34.

15. Martins SF, Amorim R, Viana-Pereira M, Pinheiro C, Costa RF, Silva P, Couto C, Alves S, Fernandes S, Vilaça S, Falcão J, Marques H, Pardal F, Rodrigues M, Preto A, Reis RM, Longatto-Filho A, Baltazar F. Significance of glycolytic metabolism-related protein expression in colorectal cancer, lymph node and hepatic metastasis. BMC Cancer 2016;16:535.

16. Altenberg B, Greulich KO. Genes of glycolysis are ubiquitously overexpressed in 24 cancer classes. Genomics 2004; 84(6):1014-20.

17. Jiang B. Aerobic glycolysis and high level of lactate in cancer metabolism and microenvironment. Genes Dis 2017;4(1):25-7.

18. Beckert S, Farrahi F, Aslam RS, Scheuenstuhl H, Konigsrainer A, Hussain MZ, Hunt TK. Lactate stimulates endothelial cell migration. Wound Repair Regen 2006;14(3):321-4

19. Brizel DM, Schroeder T, Scher RL, Walenta S, Clough RW, De- 
whirst MW, Mueller-Klieser W. Elevated tumor lactate concentrations predict for an increased risk of metastases in head-and-neck cancer. Int J Radiat Oncol Biol Phys 2001;51(2):349-53.

20. Dhup S, Dadhich RK, Porporato PE, Sonveaux P. Multiple biological activities of lactic acid in cancer: influences on tumor growth, angiogenesis and metastasis. Curr Pharm Des 2012;18(10):1319-30.

21. Goetze K, Walenta S, Ksiazkiewicz M, Kunz-Schughart LA, Mueller-Klieser W. Lactate enhances motility of tumor cells and inhibits monocyte migration and cytokine release. Int J Oncol 2011;39(2):45363.

22. Fischer K, Hoffmann P, Voelk1 S, Meidenbauer N, Ammer J, Edinger M, Gottfried E, Schwarz S, Rothe G, Hoves S, Renner K, Timischl B, Mackensen A, Kunz-Schughart L, Andreesen R, Krause SW, Kreutz M. Inhibitory effect of tumor cell-derived lactic acid on human T cells. Blood 2007;109(9):3812-9.

23. Gottfried E, Kunz-Schughart LA, Ebner S, Mueller-Klieser W, Hoves S, Andreesen R, Mackensen A, Kreutz M. Tumor-derived lactic acid modulates dendritic cell activation and antigen expression. Blood 2006;107(5):2013-21.

24. Choi SY, Collins CC, Gout PW, Wang Y. Cancer-generated lactic acid: a regulatory, immunosuppressive metabolite? J Pathol 2013;230(4):350-5.

25. Polet F, Feron O. Endothelial cell metabolism and tumour angiogenesis: glucose and glutamine as essential fuels and lactate as the driving force. J Intern Med 2013;273(2):156-65.

26. De Saedeleer CJ, Copetti T, Porporato PE, Verrax J, Feron O, Sonveaux P. Lactate activates HIF-1 in oxidative but not in Warburg-phenotype human tumor cells. PLoS One 2012;7(10):e46571.

27. Vegran F, Boidot R, Michiels C, Sonveaux P, Feron O. Lactate influx through the endothelial cell monocarboxylate transporter MCT1 supports an NF-kappaB/IL-8 pathway that drives tumor angiogenesis. Cancer Res 2011;71(7):2550-60.

28. Hirschhaeuser F, Sattler UG, Mueller-Klieser W. Lactate: a metabolic key player in cancer. Cancer Res 2011;71(22):6921-5.

29. Weinhouse S. Hepatomas. Science 1967;158(3800):542-3.

30. Jose C, Bellance N, Rossignol R. Choosing between glycolysis and oxidative phosphorylation: a tumor's dilemma? Biochim Biophys Acta 2011;1807(6):552-61.

31. Moreno-Sanchez R, Rodriguez-Enriquez S, Marin-Hernandez A, Saavedra E. Energy metabolism in tumor cells. FEBS J 2007;274(6):1393418.

32. Martin M, Beauvoit B, Voisin PJ, Canioni P, Guerin B, Rigoulet M. Energetic and morphological plasticity of C6 glioma cells grown on 3-D support; effect of transient glutamine deprivation. J Bioenerg Biomembr 1998;30(6):565-78.

33. Simonnet H, Alazard N, Pfeiffer K, Gallou C, Beroud C, Demont J, Bouvier R, Schägger H, Godinot C. Low mitochondrial respiratory chain content correlates with tumor aggressiveness in renal cell carcinoma. Carcinogenesis 2002;23(5):759-68.

34. Simonnet H, Demont J, Pfeiffer K, Guenaneche L, Bouvier R, Brandt U, Schagger H, Godinot C. Mitochondrial complex I is deficient in renal oncocytomas. Carcinogenesis 2003;24(9):1461-6.

35. Bonora E, Porcelli AM, Gasparre G, Biondi A, Ghelli A, Carelli V, Baracca A, Tallini G, Martinuzzi A, Lenaz G, Rugolo M, Romeo G.
Defective oxidative phosphorylation in thyroid oncocytic carcinoma is associated with pathogenic mitochondrial DNA mutations affecting complexes I and III. Cancer Res 2006;66(12):6087-96.

36. Bellance N, Benard G, Furt F, Begueret H, Smolkova K, Passerieux E, Delage JP, Baste JM, Moreau P, Rossignol R. Bioenergetics of lung tumors: alteration of mitochondrial biogenesis and respiratory capacity. Int J Biochem Cell Biol 2009;41(12):2566-77.

37. Baracca A, Chiaradonna F, Sgarbi G, Solaini G, Alberghina L, Lenaz G. Mitochondrial Complex I decrease is responsible for bioenergetic dysfunction in K-ras transformed cells. Biochim Biophys Acta 2010;1797(2):314-323.

38. Zu XL, Guppy M. Cancer metabolism: facts, fantasy, and fiction. Biochem Biophys Res Commun 2004;313(3):459-65.

39. Mandujano-Tinoco EA, Gallardo-Perez JC, Marin-Hernandez A, Moreno-Sanchez R, Rodriguez-Enriquez S. Anti-mitochondrial therapy in human breast cancer multi-cellular spheroids. Biochim Biophys Acta 2013;1833(3):541-51.

40. Teodoro JS, Palmeira CM, Rolo AP. Mitochondrial membrane potential (DeltaPsi) fluctuations associated with the metabolic states of mitochondria. Methods Mol Biol 2018;1782:109-19.

41. Zhang BB, Wang DG, Guo FF, Xuan C. Mitochondrial membrane potential and reactive oxygen species in cancer stem cells. Fam Cancer 2015;14(1):19-23.

42. Chen LB. Mitochondrial membrane potential in living cells. Annu Rev Cell Biol 1988;4:155-81

43. Summerhayes IC, Lampidis TJ, Bernal SD, Nadakavukaren JJ, Nadakavukaren KK, Shepherd EL, Chen LB. Unusual retention of rhodamine 123 by mitochondria in muscle and carcinoma cells. Proc Natl Acad Sci U S A 1982;79(17):5292-6.

44. Wong JR, Chen LB. Recent advances in the study of mitochondria in living cells. In: Advances in Cell Biology, Vol. 2, pp. 263-290. New York: JAI Press, Inc. 1988

45. Chen LB, Rivers EN. Mitochondria in cancer cells. In: D Carney, K Sikora (eds.), Genes and Cancer, pp. 127-35:1990.

46. Davis S, Weiss MJ, Wong JR, Lampidis TJ, Chen LB. Mitochondrial and plasma membrane potentials cause unusual accumulation and retention of rhodamine 123 by human breast adenocarcinoma-derived MCF-7 cells. J Biol Chem 1985;260(25):13844-50.

47. Kang JH, Lee SH, Lee JS, Nam B, Seong TW, Son J, Jang H, Hong KM, Lee C, Kim SY. Aldehyde dehydrogenase inhibition combined with phenformin treatment reversed NSCLC through ATP depletion. Oncotarget 2016;7(31):49397-410.

48. Patel MS, Korotchkina LG. Regulation of the pyruvate dehydrogenase complex. Biochem Soc Trans 2006;34(Pt 2):217-22.

49. Stacpoole PW, Kurtz TL, Han Z, Langaee T. Role of dichloroacetate in the treatment of genetic mitochondrial diseases. Adv Drug Deliv Rev 2008;60(13-14):1478-87.

50. Saunier E, Benelli C, Bortoli S. The pyruvate dehydrogenase complex in cancer: An old metabolic gatekeeper regulated by new pathways and pharmacological agents. Int J Cancer 2016;138(4):809-17.

51. Koukourakis MI, Giatromanolaki A, Bougioukas G, Sivridis E. Lung cancer: a comparative study of metabolism related protein expression in cancer cells and tumor associated stroma. Cancer Biol Ther 2007;6(9):1476-9. 
52. Vander Heiden MG, Cantley LC, Thompson CB. Understanding the Warburg effect: the metabolic requirements of cell proliferation. Science 2009;324(5930):1029-33.

53. Michelakis ED, Webster L, Mackey JR. Dichloroacetate (DCA) as a potential metabolic-targeting therapy for cancer. Br J Cancer 2008;99(7):989-94.

54. Roche TE, Hiromasa Y. Pyruvate dehydrogenase kinase regulatory mechanisms and inhibition in treating diabetes, heart ischemia, and cancer. Cell Mol Life Sci 2007;64(7-8):830-49.

55. Sun RC, Fadia M, Dahlstrom JE, Parish CR, Board PG, Blackburn AC. Reversal of the glycolytic phenotype by dichloroacetate inhibits metastatic breast cancer cell growth in vitro and in vivo. Breast Cancer Res Treat 2010;120(1):253-60.

56. McFate T, Mohyeldin A, Lu H, Thakar J, Henriques J, Halim ND, Wu H, Schell MJ, Tsang TM, Teahan O, Zhou S, Califano JA, Jeoung NH, Harris RA, Verma A. Pyruvate dehydrogenase complex activity controls metabolic and malignant phenotype in cancer cells. J Biol Chem 2008;283(33):22700-8

57. Kim JW, Tchernyshyov I, Semenza GL, Dang CV. HIF-1-mediated expression of pyruvate dehydrogenase kinase: a metabolic switch required for cellular adaptation to hypoxia. Cell Metab 2006;3(3):177-85. 58. Papandreou I, Cairns RA, Fontana L, Lim AL, Denko NC. HIF-1 mediates adaptation to hypoxia by actively downregulating mitochondrial oxygen consumption. Cell Metab 2006;3(3):187-97.

59. Holness MJ, Sugden MC. Regulation of pyruvate dehydrogenase complex activity by reversible phosphorylation. Biochem Soc Trans 2003;31(Pt 6):1143-51.

60. Potter M, Newport E, Morten KJ. The Warburg effect: 80 years on. Biochem Soc Trans 2016;44(5):1499-505.

61. Ozden O, Park SH, Wagner BA, Song HY, Zhu Y, Vassilopoulos A, Jung B, Buettner GR, Gius D. SIRT3 deacetylates and increases pyruvate dehydrogenase activity in cancer cells. Free Radic Biol Med 2014;76:163-72.

62. Park J, Chen Y, Tishkoff DX, Peng C, Tan M, Dai L, Xie Z, Zhang Y, Zwaans BM, Skinner ME, Lombard DB, Zhao Y. SIRT5-mediated lysine desuccinylation impacts diverse metabolic pathways. Mol Cell 2013;50(6):919-30.

63. Koukourakis MI, Giatromanolaki A, Sivridis E, Gatter KC, Harris AL, Tumor Tumor and Angiogenesis Research Group. Pyruvate dehydrogenase and pyruvate dehydrogenase kinase expression in non small cell lung cancer and tumor-associated stroma. Neoplasia 2005;7(1):1-6. 64. Blouin JM, Penot G, Collinet M, Nacfer M, Forest C, Laurent-Puig P, Coumoul X, Barouki R, Benelli C, Bortoli S. Butyrate elicits a metabolic switch in human colon cancer cells by targeting the pyruvate dehydrogenase complex. Int J Cancer 2011;128(11):2591-601.

65. Sutendra G, Dromparis P, Kinnaird A, Stenson TH, Haromy A, Parker JM, McMurtry MS, Michelakis ED. Mitochondrial activation by inhibition of PDKII suppresses HIF1a signaling and angiogenesis in cancer. Oncogene 2013;32(13):1638-50.

66. Hur H, Xuan Y, Kim YB, Lee G, Shim W, Yun J, Ham IH, Han SU. Expression of pyruvate dehydrogenase kinase-1 in gastric cancer as a potential therapeutic target. Int J Oncol 2013;42(1):44-54.

67. Abildgaard C, Dahl C, Basse AL, Ma T, Guldberg P. Bioenergetic modulation with dichloroacetate reduces the growth of melanoma cells and potentiates their response to BRAFV600E inhibition. J Transl Med 2014;12:247.

68. Wigfield SM, Winter SC, Giatromanolaki A, Taylor J, Koukourakis ML, Harris AL. PDK-1 regulates lactate production in hypoxia and is associated with poor prognosis in head and neck squamous cancer. Br J Cancer 2008;98(12):1975-84.

69. Sun W, Zhou S, Chang SS, McFate T, Verma A, Califano JA. Mitochondrial mutations contribute to HIF1alpha accumulation via increased reactive oxygen species and up-regulated pyruvate dehydrogenease kinase 2 in head and neck squamous cell carcinoma. Clin Cancer Res 2009;15(2):476-84.

70. Lu CW, Lin SC, Chien CW, Lin SC, Lee CT, Lin BW, Lee JC, Tsai SJ. Overexpression of pyruvate dehydrogenase kinase 3 increases drug resistance and early recurrence in colon cancer. Am J Pathol 2011;179(3):1405-14.

71. Shen YC, Ou DL, Hsu C, Lin KL, Chang CY, Lin CY, Liu SH, Cheng AL. Activating oxidative phosphorylation by a pyruvate dehydrogenase kinase inhibitor overcomes sorafenib resistance of hepatocellular carcinoma. Br J Cancer 2013;108(1):72-81.

72. Fujiwara S, Kawano Y, Yuki H, Okuno Y, Nosaka K, Mitsuya H, Hata H. PDK1 inhibition is a novel therapeutic target in multiple myeloma. Br J Cancer 2013;108(1):170-8.

73. Baumunk D, Reichelt U, Hildebrandt J, Krause H, Ebbing J, Cash H, Miller K, Schostak M, Weikert S. Expression parameters of the metabolic pathway genes pyruvate dehydrogenase kinase-1 (PDK$1)$ and DJ-1/PARK7 in renal cell carcinoma (RCC). World J Urol 2013;31(5):1191-6.

74. Sugden MC, Holness MJ. Recent advances in mechanisms regulating glucose oxidation at the level of the pyruvate dehydrogenase complex by PDKs. Am J Physiol Endocrinol Metab 2003;284(5):E855-62.

75. Sugden MC, Holness MJ. Mechanisms underlying regulation of the expression and activities of the mammalian pyruvate dehydrogenase kinases. Arch Physiol Biochem 2006;112(3):139-49.

76. Stacpoole PW. Therapeutic Targeting of the pyruvate dehydrogenase complex/pyruvate dehydrogenase kinase (PDC/PDK) axis in cancer. J Natl Cancer Inst 2017;109(11).

77. Zhang W, Zhang SL, Hu X, Tam KY. Targeting tumor metabolism for cancer treatment: is pyruvate dehydrogenase kinases (PDKs) a viable anticancer target? Int J Biol Sci 2015;11(12):1390-400.

78. Kang JH, Lee SH, Hong D, Lee JS, Ahn HS, Ahn JH, Seong TW, Lee CH, Jang H, Hong KM, Lee C, Lee JH, Kim SY. Aldehyde dehydrogenase is used by cancer cells for energy metabolism. Exp Mol Med 2016;48(11):e272.

79. Kim SY. Cancer Energy Metabolism: shutting power off cancer factory. Biomol Ther (Seoul) 2018;26(1):39-44.

80. Hong SM, Hwang SW, Wang T, Park CW, Ryu YM, Jung JH, Shin JH, Kim SY, Lee JL, Kim CW, Yoon G, Kim KH, Myung SJ, Choi KY. Increased nicotinamide adenine dinucleotide pool promotes colon cancer progression by suppressing reactive oxygen species level. Cancer Sci 2019;110(2):629-38.

81. Lee JS, Kang JH, Lee SH, Hong D, Son J, Hong KM, Song J, Kim SY. Dual targeting of glutaminase 1 and thymidylate synthase elicits death synergistically in NSCLC. Cell Death Dis 2016;7(12):e2511. 82. Stone OA, El-Brolosy M, Wilhelm K, Liu X, Romao AM, Grillo E, 
Lai JKH, Günther S, Jeratsch S, Kuenne C, Lee IC, Braun T, Santoro MM, Locasale JW, Potente M, Stainier DYR. Loss of pyruvate kinase M2 limits growth and triggers innate immune signaling in endothelial cells. Nat Commun 2018;9(1):4077.

83. Morita M, Sato T, Nomura M, Sakamoto Y, Inoue Y, Tanaka R, Ito S, Kurosawa K, Yamaguchi K, Sugiura Y, Takizaki H, Yamashita Y, Katakura R, Sato I, Kawai M, Okada Y, Watanabe H, Kondoh G, Matsumoto S, Kishimoto A, Obata M, Matsumoto M, Fukuhara T, Motohashi H, Suematsu M, Komatsu M, Nakayama KI, Watanabe T,
Soga T, Shima H, Maemondo M, Tanuma N. PKM1 confers metabolic advantages and promotes cell-autonomous tumor cell growth. Cancer Cell 2018;33(3):355-67.

84. Lee J, Yesilkanal AE, Wynne JP, Frankenberger C, Liu J, Yan J, Elbaz M, Rabe DC, Rustandy FD, Tiwari P, Grossman EA, Hart PC, Kang C, Sanderson SM, Andrade J, Nomura DK, Bonini MG, Locasale JW, Rosner MR. Effective breast cancer combination therapy targeting BACH1 and mitochondrial metabolism. Nature 2019;568(7751):254-8. 